\title{
“Ajeg Bali” Discourse In Dynamics Of Craft Of Ceremonial Tools In Bali
}

\author{
Ni Kadek Karuni \\ Faculty of Fine Art and Design ISI \\ Denpasar \\ Art Craff \\ Denpasar, Indonesia \\ kadekkaruni@ymail.com
}

\author{
I Wayan Suardana \\ Faculty of Fine Art and Design ISI \\ Denpasar \\ Art Craff \\ Denpasar, Indonesia \\ suar.tulu63@gmail.com
}

\author{
$3^{\text {rd }}$ I Made Supartha \\ Faculty of Fine Art and Design ISI \\ Denpasar \\ Art Craff \\ Denpasar, Indonesia \\ madesuparta@isi-dps.com
}

\begin{abstract}
Nowadays, increasing public interest to carry out religious ceremoniesin Bali is also based on the responsibility to preserve Balinese art and culture which are implemented in "Ajeg Bali Discourse". To support the ceremony, it needs various tools in accordance with the form and function of the ceremony that will be presented.This study aims to reveal in depth about the social function of ceremonial tools in Bali related to changes in mental attitude and enthusiasm of society in supporting AjegBali discourse. The method used is qualitative method with analytical descriptive analysis through the sociology approach.Besides having a practical function as a place of offerings, the results of the study show that the ceremonial tools also have a social function, which determines the social position and prestige value of the community that uses it.The community is proud while using beautiful and luxury ceremony tools, and more confident to uphold to the temple. Increasing the needs of the community to the ceremonial tools inspires the artisans to develop their creativity in creating new products that are more unique, artistic, and interesting by utilizing various materials while using some techniques, such as carving, weaving, stitching, and painting. Dynamics ofcraft in dynamic ceremonial tools impact on increasing productivity and economic value of artisans.
\end{abstract}

Keywords: Ajeg Bali, Dynamics, ceremonial tools

\section{INTRODUCTION}

Balinese society were flexible, open and selective in accepting external cultures that came through tourism. Acculturation between foreign and Balinese culture was common where a new culture was born in line with local culture (Ardana, 2007: 7). Even so, Balinese scholars and policy holders worried about the swift influences that influenced the culture of the noble Balinese tradition. Various efforts and actions were taken by the government to anticipate this. The Governor of Bali Ida Bagus Mantra built Werdhi Budaya Cultural Park as a center for art events. Moreover, he also initiated Bali Arts Festival (PKB) which aimed to revitalize Balinese extinct arts, as well as the publication of various Balinese arts and cultures for local, national and international communities. The most basic concept of carrying out Bali Arts Festival was to preserve Balinese culture which might be eroded by modernization culture. Therefore, the main concept of "Ajeg Bali" had been stated in this annual agenda; however, it was only action oriented without any supports by a vigorous discourse.

Ajeg Bali discourse was arranged when Bali experienced a major disaster namely Bali Bomb I on October 12, 2002. The Balinese people were lulled by the sparkling tourism frenzy and the belief of Bali as the safest and most comfortable area.

The Bali bomb is a sign, a warning sign in order to make Balinese people had attention in maintaining the harmony and identity of Bali so that "Ajeg" did not disappear because of changes. Starting from this, there was a discourse to preserve Bali. "Ngiring sareng-sareng ngerajegang Jagat Baline (let's take care of Bali's identity) (Agung, 2005: xii).
The society began to preserve Bali in every side of life. In order to achieve balance and harmony between body and spirit, Balinese people began to increase their spiritual values. Besides performing various ceremonies, there were also many people went to various temples in all regions around Bali. This activity often referred to "Religious Recreation" which was defined as devotional while traveling.

The increasing activities of religious and customary ceremonies and religious recreation of Balinese people required various forms and types of unique and artistic ceremonial tools. In addition, Balinese people also had a high sense of prestige, especially regarded to the appearance of the offering. The soul and nature of this society would eventually produce works of art that were increasingly varies because of the demands of beauty in an offering. This was also based on what Balinese society did was a responsibility in contributing Ajeg Bali discourse. In supporting Ajeg Bali discourse, Balinese people were very enthusiastic to have various forms and types of ceremonial tools. People did not want to miss the trendy ritual products at certain times. This condition was an opportunity for artisans to create new products that had artistic value besides functional value. The form and type of ceremonial tools appeared in the form of wood carvings, plaits, prints, and assemblies.

Gianyar is one of the birthplace of craft ceremonial tools that spread in several districts, such as Tegallalang, Sukawati, Blahbatuh, and Tampaksiring. Various forms and types of ceremonies tools included wanci, tokasi, pemuspan, and bokoran, which used wood, rattan, palm leaves, with wood carving, woven, mold, and sungging techniques. This phenomenon was very interesting to be studied more deeply, why the Balinese people were very 
enthusiastic in supporting Ajeg Bali discourse by trying to have a variety of ceremonial tools, as well as why the products of ceremonial tools were used in order to show prestige and appearance in traditional and religious ceremonies.

\section{THEORETICAL REVIEW Ajeg Bali}

Balinese people had obligation to maintain and protect Balinese art and culture in order to remain strong and sustainable. Bali which was Ajeg did not mean to keep Bali being static and stagnant, fragile and weathered, barren and old-fashioned, but Bali which was Ajeg was holistic, democratic, whole, safe, united, prosperous, and healthy both life and mind, in accordance with the purpose of Hinduism: "Moksartham Jagadhita Ya Ca Iti Dharma" whose manifestation was the result of a joint work (Kerepun, 2004: 47). The noble of Balinese culture needed to be preserved in order to avoid it eroded by time and globalization in all aspects of lives. In order to preserve Bali, it could be done by digging and awakening culture that was almost extinct, preserving and protecting existing cultures well and consistently, and developing a culture in accordance with desa, kala, patra and development era. These opinions had relevance with the dynamics of the art of crafting ceremonial tools in Gianyar, it is because various ceremonial tools became one of the important instruments in ceremonial activities that needed to be kept.

\section{Lifestyle and Self Imaging.}

The high responsibility of Balinese people to participate in preserving Bali referred to a new order of life in society that led to a religious lifestyle. The society seemed to show themselves as someone who was obedient in carrying out a religion in which it had indirectly taken part in preserving Bali in their daily life.

Generally, lifestyle was defined as someone's characteristics that could be observed, which also marked the system of values and attitudes towards themselves and their environment. These characteristics related to the use of time, money, space and objects that related to someone. Lifestyle, thus, was a combination and totality of ways, rules, habits, choices and objects to support someone, whose implementation was based on a value system or a particular belief system (Piliang, 2010: 247). The consumptive lifestyle of the people was the basic motivation that drove human behavior to the desire of consuming the material in the market so that the society became consumptive (Luly 1993 in the atmosphere, 2010: 89). This desire was even more intense because humans were entangled in consumption politics, in which the society used consumption as an ideology. Likewise, the values and meanings of life, the actualization and existence of the self were obtained through the act of consumption (Piliang, 1998). As a result, consumerism was a spirit of developing religion market in Balinese society. (Bring atmaja, 2010: 89). The consumerism lifestyle was a style of consumption that was sustained by a continuous process of differentiation through the mechanism of sign, image and symbolic meanings. (Pilliang, 2010: 238). In many ways, consumerism was opposed to various forms of wisdom that were taught by local traditions, such as simplicity, togetherness, tolerance and compassion (Pilliang, 2010: 209). Therefore, looking at Balinese life, there were two obscured values, namely the use value and symbolic value. Things that were consumed by Balinese is often not in line with the needs of them, but it was based on desire. As a result, the Balinese did not become users but they became consumers. (Atmaja bring, 2010: 92) The desire to consume an item was closer because humans were also entangled in the politics of imaging, meaning whatever they consumed was the appearance of the face to look modern, rich. As a result, humans consumed something based on use value, and also the symbolic value (social status, class, prestige) (piliang, 1998, Aldin, 2004 in Bawa Atmaja, 2010: 99)

The lifestyle of Balinese people who wanted to have something and be able to improve their social status in society were some good household furniture that were used to support secular needs as well as ceremonial tools with various forms and functions. A variety of ceremonial tools with unique and elegant Balinese ornaments became the target of society to support their religious lifestyle. The number of ceremonial tools needed by the society became a

business opportunity for craftsmen to create a variety of products that were more varies. The development of various handicraft ceremonial tools as one form of Balinese culture into mass products produced in large quantities could not be separated from the entry of a new era, the era of capitalism which sought to exploit various things into economic goods. This was also the case with the ceremonial crafting tools in Bali that were now starting to be mass-produced, which in production techniques had also developed such as the manufacture of products with printing techniques. Even the order did not have to be done by meeting directly, but it could be via telephone and email online. Consumers who needed their social existence in society, while craftsmen continually produced ceremonial products with various styles and creativity cause craftsmen to get economic benefits to support their life's prosperity.

\section{RESEARCH METHODS}

The research method was a qualitative method with analytic descriptive analysis through a sociological approach. The theory used to discuss this problem was the theory of social change. Wilbert Moore in Gunawan (2014) explained that social change as an important change of social structure, such as patterns and social interactions that involved cultural norms, values and symptoms. Soemandjan (2009) explained that social change was basically very difficult to separate from cultural or cultural changes. The emergence of the religious lifestyle of Balinese people was inseparable from cultural changes and patterns of behavior in people's lives which were influenced by continuous modernization that engulfs traditional and acculturate to a new culture of united and harmony. The social life of the society would always experience change along with changes in mindset and the behavior of the supporting society.

\section{DISCUSSION}

Besides the frenzy of modernization life in Bali as a 
result of the rapid influence of tourism and information technology, Balinese people still maintain and uphold Bali's unique and noble culture.

The tremendous of Balinese culture rose various discourses, whether Balinese were still original, whether Balinese immortality had faded, changed, left behind a noble tradition of culture. These were considered to be faded due to the intense influences of external influences. Moreover, these things also happened because Balinese lifestyle and behavior had changed a lot. This case led the society introduced discourse, namely "Ajeg Bali" which was used as the main fortress to maintain the authenticity and dignity of Balinese people who were unique and acclaimed. Ajeg Bali was Bali (Sekala-Niskala) which was sustainable and supported by Balinese people with the advancement of science and technology, in which it was based on Hinduism values. This meant that Ajeg was Bali which developed in line with the advancement of science and technology, the progress of the Balinese mindset and the values of Hinduism. In order to maintain Balinese constancy, it was appropriate for Bali's perpetrators to base themselves with Tri Semaya, namely: Atita (past), Wartamana (present), and Nagata (future) (Adiputra, 2005: 185).

Since long time ago, Balinese culture had change due to external influences. These changes did not dismantle and revoke Balinese indigenous culture, but it always influenced and acculturated each other, so that a new culture was born which received well by Balinese people. These culture would develop in the life continuously, so that the new culture became a traditional culture. This could be proved by a new tradition of culture influenced by external influences, such as Balinese ornamentation, namely Patra Cina, Patra Wulanda, Patra Mesir, Patra Bangkok, and many others. (Gelebet, dalam Karuni 2013:197). Ajeg Bali discourse was an effort to maintain Balinese culture in order to avoid extinction. In addition, the society had responsibility in preserving Balinese culture with various traditional and religious activities which were presented by Balinese identity. In order to show local identity, it should be supported by activities and artifacts of original Balinese value, especially those which related to traditional ceremonies and religious tools. In addition, it was not only aimed as tools that had religious value, but also had the function of propane. People would feel embarrassed if they did not support Ajeg Bali's discourse as participant in preserving Balinese culture.

Balinese people enthusiastically accepted this discourse and practiced it in their daily lives by carrying out various unique and original activities of tradition. The effort of Ajeg Bali discourse in daily life raised people's religious lifestyles, such as increasing the activities which were oriented to traditional and religious activities. People's interest in carrying out rituals increased; moreover, individuals and families of the society often went to various temples which spread throughout Bali in order to ask for protection and welfare.

Ajeg Bali discourse unwittingly had changed a new order of people's lives from a modern lifestyle which was very free and open to modern life in harmony with religious activities. Modernization was hand in hand with religious life that was implemented with real spiritual action. Society always showed themselves with a religious attitude in modern behavior and daily appearance in doing all activities.

People began to get closer to the almighty God by performing daily prayers even though they were not accompanied by ceremonies. As Hinduism, the society always prioritized Him by praying, asking for guidance and safety before doing any routine activities. On certain occasions, on holidays, they spend their time to gather with family by carrying out prayer activities to various holy places in Bali and outside Bali.

In simple way, people's lives could not be separated from the religious atmosphere in which every day they became accustomed to praying in temple or other holy places by using very simple clothes with a quiet and sincere heart. Every day, they began to be able to use senteng and put their hands together, praying to the Almighty. They would feel something less or awkward if they did not carry out this activity every day.

An order of life with full peace and harmony, the demands of secular needs were always alongside with spiritual life. These became ideal and purpose of society to achieve a balanced physical and spiritual well-being in life, so that peace and tranquility of life would be well embraced. On the other hand, the problem was that humans were always weak on temptations in which desires and wills could not be prevented.

The lifestyle of religious society was not only as an effort to preserve Balinese culture, but also as a result of the increasing economic of the society. The society realized that what things which had been obtained was the generosity of the Almighty God in bestowing mercy so that life was carried out in the state of santhi lan jagadhita. The religious lifestyle seemed to become a Balinese tradition that should be followed so that it was not considered outdated. This was not only the appearance of a ceremony with all its equipment, but also the appearance of a person in attending the ceremony, especially those related to women. To do their prayers they had to look fashionable, with sexy and attractive clothes and attractive makeup. As an effort to participate in preserving the culture so that it remains Ajeg, the society understood it with excessive action. This order eventually created religious lifestyle of people under the confines of modern life which was full of materialistic and consumptive. Religious lifestyles were wrapped up in the increasingly consumptive lives of people who always made use of existing ones without any effort to do it themselves. This symptom could be seen from offerings which were sold in the market and also emerged of "Banten Trade" to support the religious lifestyle that had spread in the society.

In line with increasingly competitive life and needs, people were increasingly busy and always pursue the economy to support their needs. On the other side, the society was also required to do the obligation to perform rituals every day. This condition required the society to buy offerings that were ready to be offered in the market and the craftsmen. It could not be denied, this phenomenon would lead to a consumptive living system of society. Consumerism could not be avoided to strengthen the characteristics of a unique and noble society culture. Based on the creativity and innovation of 
the society to process the external influences that still existed, the influence of modernization would always alongside with harmony of traditional culture, and a new culture was born to enriches the existing culture. Furthermore, the new culture had been accepted and continued by the society in order to make a strong and intact conventional culture. The culture was not only related artifacts, but also related to the behavior and lifestyle of people who always experienced change according to their times.

The enthusiasm of people to be responsible in preserving Balinese culture which was implemented by pursuing pure and sacred of religion activities, showed the discourse of Ajeg Bali played a huge role in shaping the attitude of the society to maintain a traditional culture that was alongside with modern culture. Society supports were actualized by utilizing a variety of ceremonial tools that were very unique and interesting, in which it indicated that Ajeg Bali discourse indirectly played a huge role in the development of ceremonial facilities in Gianyar. People were very enthusiastic to have various forms and functions of ceremonial tools that were used to support the activities of religious activities carried out in each house. The ceremony tools did not only have a practical function, but also it had social functions in the society. The social status of the society would be assessed sometimes from the ceremonial means used.

Many people carried out large and luxurious ceremonies by prioritizing the appearance of purity to show themselves as someone who had a high status. The people did not understand that in Itihasa a large ceremony was explained not always have a high value than a smaller ceremony. In fact, high-value ceremonies were something carried out sincerely (nekeng twas). The ceremony was only intended to show off, more attachments to the personal ego, and as a lifestyle, the ceremony would be in vain without any values (Subawa, 2012: 125). Therefore, in carrying out the ceremony, it should be carried out in accordance with the ability and sincerity of a pure heart.

The increasing needs for ceremonial tools could be an opportunity for artisan to create more innovative work. Artisans were very observant to create something that was different and in accordance with people's tastes. In a situation like this, it turned out that craft art could be dynamically developed in accordance with the interests of consumers. It could be proved by the development of certain craft objects that were considered to have favorable market opportunities. Wood crafts, bamboo, rattan, leather, immediately attracted investors (native and foreign) to invest their capital in the development of small industries and handicrafts (Gustami, 1991, 8). At creative industry of this era, there also existed many new crafts which did not only come from tradition, but also creativity of its artisan. (Muhammad Ihsan, Sachari, 2015:133).

The description above explained that the importance of craft art role in supporting all aspects of society life, both as a means of various activities, as well as a medium to support the society's economy and increase foreign exchange. Crafts also had a very high value as a noble cultural art work with a very strong identity in each region where the craft and craft art develops.
The ceremonial craft was one of the Balinese handicrafts which had a huge opportunity to be developed in the midst of increasing the orientation of the society who paid more attention to spirituality in their life processes. The sale of craft art was a means of ceremony increasingly scattered. Along the road, shops had sprung up that sold various forms and types of craft art with various ceremonial tools. In traditional markets, there were many stalls that showcased the art of crafting ceremonial tools with various attractions. Many collectors sold handicraft products with open cars, they stopped at a crowd, both at the ceremonial place and at the night market and offered craft items for ceremonies. This was a sign that the art of crafting ceremonial facilities had been done a lot by artisan and it was widely distributed in several communities in Bali.

\section{CONCLUSION}

Balinese people were very enthusiastic to support the discourse of "Ajeg Bali" because it was based on the responsibility to continue maintaining, protecting, and developing Balinese arts and culture that had been the ancestral heritage since a long time ago. As the next generation, we were obliged to fortify Balinese culture from the onslaught of external influences which were increasingly aggressively attacking Balinese culture from various lines of society life. If Balinese culture was not guarded firmly, it would disappear into the era, the characteristics of Bali would also disappear and Bali would become obsolete and dry.

The loss of characteristics of Balinese culture would indirectly cause Balinese to be dry and poor. This was because most of the life of Balinese people depends on tourism, and the development of tourism in Bali was strongly supported by unique and interesting Balinese culture. Therefore, it was the duty of the Balinese to maintain Balinese culture as a whole in order to live throughout the ages.

The ceremonial tool was one of the Balinese cultural works which had a huge role in supporting all society activities in carrying out traditional and religious ceremonies. The ceremony tools besides had practical function, also had a social function that was as a marker of the stratification of the social status of the owners. Many people used ceremonial tools as a show of prestige and appearance in various religious activities, because Balinese activities were mostly done at ceremonial activities, in contrast to other modern societies where social activities were mostly carried out at malls or other parties. Therefore, many people chose ceremonial tools that were luxurious and elegant. Besides of the purpose to offer the best to the Almighty God, people also wanted to show their identity as rich people in other communities. People would be very confident when they carried offerings using luxurious and glittering ceremonial facilities as a sign that their lives were well established.

\section{ACKNOWLEDGEMENT}

We would like to thank DRPM Kemenristek DIKTI (Ministry of Research, Technology and Education) who had supported this research so that this research could be finished well. In addition, we also express our gratitude to our friends from LP2MPP ISI Denpasar, Crafts Study 
Program who had already given knowledge and skill to support this research.

Finally, we would like to say thank you for cultural observers, craftsmen and women organization who gave information related to this research.

\section{REFERENCES}

1. Adiputra, Gede Rudia, “Asih-Punia-Bhakti Pilar Spirit Ajeg Bali, Dialog Ajeg Bali, Paramita, Surabaya, 2004.

2. Agung, A.A. Gde Putra, Dialog Ajeg Bali Perspektif Pengamalan Agama Hindu, Paramita, Surabaya. 2005

3. Ardana, I Gusti Gede, Pemberdayaan Kearifan Lokal Masyarakat Bali Dalam Menghadapi Budaya Global, Pustaka Tarukan Agung, Denpasar, 2007.

4. Atmadja, Nengah Bawa, , Ajeg Bali Gerakan, Identutas Kultural, dan Globalisasi, LKiS, Yogyakarta, 2010.

5. Gunawan, Daddi H, Perubahan Sosial di Pedesaan Bali, Marjin Kiri, Tangerang, 2014.

6. Gustami SP., "Seni Kriya Indonesia:Dilema Pembinaan dan Pengembangannya", Pidato Ilmiah pada Dies Natalis VII ISI Yogyakarta, 1991.

7. Karuni, Penerapan Ornamen Baru Pada Seni Ukir Bangunan di Gianyar Bali, Dalam Jurnal Mudra Volume 28 no.2 Institut Seni Indonesia Denpasar Bali, 2013.

8. Kerepun, Made, Kembar, "Analisis SWOT dalam strategi mencapai dan Memelihara Ajeg Bali”, Dialog Ajeg Bali, Paramita Surabaya, 2004.

9. Muhammad Ihsan, Sachari, Relasi Selera Pengrajin Dan Selera Konsumen Terhadap Produk Rumah Tangga Seharihari, Dalam Jurnal Mudra, Volume 30 no. 2 Institut Seni Indonesia Denpasar, 2015.

10. Piliang, Yasraf Amir, Dunia Yang Dilipat:Tamasya melampaui Batas-Batas Kebudayaan, Bandung, 2011.

11. Subawa, I Gede, Reformasi Ritual, Mentradisikan Agama bukan Mengagamakan Tradisi, Pustaka Bali Post, Denpasar, 2012. 